\title{
Haematological Profile of Children With Sickle Cell Anaemia in Steady State
}

\author{
Rasaki Aliu $^{1}$, Jalo Iliya ${ }^{1}$, Oladeji R. Quadri ${ }^{2}$, Olayinka R. Ibrahim ${ }^{3}$, Ezra Daniel ${ }^{4}$ \\ 1. Pediatrics, Gombe State University/Federal Teaching Hospital, Gombe, NGA 2. Otorhinolaryngology, Gombe State \\ University/Federal Teaching Hospital, Gombe, NGA 3. Pediatrics, Federal Medical Center, Katsina, NGA 4. Pediatrics, \\ Federal Teaching Hospital, Gombe, NGA
}

Corresponding author: Rasaki Aliu, aliu.abdurrazaq11@gmail.com

\section{Abstract}

\section{Introduction}

Sickle cell anaemia (SCA) is an inherited, autosomal recessive condition that results from a mutation in the $\beta$-globin gene. Vascular occlusion is the underlying mechanism behind a myriad of complications encountered. This vascular occlusion is primarily caused by the increased tendency of red blood cells (RBC) to adhere to the vascular endothelium, and the activation of platelets and total leucocyte count (TLC), hence the need for a steady-state haematological profile in these patients.

\section{Method}

This was a cross-sectional study conducted over four months at a sickle cell clinic. Haemoglobin (Hb) concentration, haematocrit, platelet, TLC, mean corpuscular volume (MCV), mean corpuscular haemoglobin $(\mathrm{MCH})$ and mean corpuscular haemoglobin concentration (MCHC) of the subjects were recorded and analysed.

\section{Results}

Ninety-nine subjects aged 1-18 years were recruited for the study. There were 53 (53.5\%) males. Leucocytosis was seen in 80 (80.8\%), anaemia in 99 (100\%), and thrombocytosis in 30 (30.3\%) patients. The mean $\mathrm{Hb}$, TLC and platelets were $7.9 \pm 1.3 \mathrm{~g} / \mathrm{dl}, 14.3 \pm 4.5 \times 10^{3} / \mathrm{mm}^{3}$ and $391.5 \pm 182.6 \times 10^{3} / \mathrm{mm}^{3}$ respectively. Mean MCV, MCH and MCHC were $81.3 \pm 7.1 \mathrm{fl}, 28.6 \pm 2.9 \mathrm{pg}$ and $35.2 \pm 1.7 \mathrm{~g} / \mathrm{dl}$ respectively. Children aged one to four years had the highest TLC $(\mathrm{p}=0.002)$ but the lowest mean $\mathrm{Hb}$ and platelet $(\mathrm{p}=0.094$ and 0.06$)$ respectively. The mean MCV, MCH and MCHC were lowest in children aged one to four years $(\mathrm{p}=0.047$, 0.001 and 0.001).

\section{Conclusion}

Anaemia, leucocytosis and thrombocytosis are characteristics features of children with SCA, especially in male and younger subjects. Although Iron markers are generally normal in children with SCA, those under the age of five years tend to have lower values.

Review began 10/01/2020 Review ended 10/12/2020 Published 10/18/2020

\section{() Copyright 2020}

Aliu et al. This is an open access article distributed under the terms of the Creative Commons Attribution License CC-BY 4.0., which permits unrestricted use, distribution, and reproduction in any medium, provided the original author and source are credited.
Categories: Pediatrics, Hematology

Keywords: sickle cell children, haematological profile, iron markers, vascular occlusion

\section{Introduction}

Globally, more than 300,000 babies with sickle cell disease are born each year [1]. More than two-thirds of these births occur in Africa, with Nigeria accounting for half $(150,000)$ of the victims [1]. Although Nigeria as a country has the highest burden of sickle cell anaemia (SCA) in the world [1], most of the cases are reported in the northern region of the country, where this study was conducted, which has a prevalence rate of $23.7 \%$ $[2]$.

SCA affects virtually every organ of the body [3]. While infection and vaso-occlusive and anaemic crises are common manifestations in children with SCA, vaso-occlusion has been reported as the most common manifestation and the most common cause of hospitalization, organ failure, and death in children with SCA [4]. This vaso-occlusion, which underlies many pathogenic mechanisms behind myriad complications in children with SCA, is primarily caused by adherence of red blood cells (RBC) to the vascular endothelium and thus anaemia, white blood cells (WBC) and platelet activation, leading to elevated values with potentials for developing complications [5]. Determining the steady-state values of these parameters and associated factors are therefore critical in detecting early deviations from the norm and prompt intervention. In this study, we describe the haematological indices of children with SCA in steady state. This study is the first of its kind to be conducted in North-East Nigeria, and we believe the findings from this study will add to the existing body of knowledge and form a reference template related to SCA for our environment and 
regional settings.

\section{Materials And Methods}

\section{Study site}

This was a cross-sectional descriptive study conducted at the sickle cell disease centre of the Federal Teaching Hospital, Gombe (FTHG), North-East Nigeria, and lasted four months from May to August 2018. The FTHG is a tertiary institution that has a sickle cell centre, which is one of the six sickle cell centres spread across the six geo-political zones in Nigeria.

\section{Inclusion criteria}

Children aged 1-18 years who were on follow-up at the sickle cell clinic in FTHG, in steady state (defined as the absence of fever and crisis in the previous four weeks or more in a child who was not on any medication other than routine folic acid and prophylactic antimalarial drug) were recruited after obtaining consent from their parents. Assent was also obtained from children aged seven years and above.

\section{Exclusion criteria}

Children who were on hydroxyurea were excluded as this would alter the steady-state haematological indices in SCA. Those who had received a blood transfusion within the previous month were also excluded.

\section{Sampling technique}

The researcher and the research assistant met with the staff of the sickle cell clinic a week before the commencement of the study and the information about the study was provided. Thereafter, the caregivers and the children were met weekly on their clinic days (Wednesday) early in the morning, and subjects were recruited consecutively after obtaining written informed consent, which included information about the study. Structured questionnaires were administered and $5 \mathrm{ml}$ of venous blood samples were taken from the subjects for a complete blood count.

\section{Ethical clearance}

Ethical approval was obtained from the Research and Ethics committee (REC) of FTHG.

\section{Data analysis}

Data were processed and analysed using IBM SPSS Statistical software version 23.0 (IBM, Armonk, NY). The mean and standard deviations were computed for continuous variables such as haemoglobin $(\mathrm{Hb})$, white blood cells (WBC) and platelet counts; the independent t-test was used to determine the level of statistically significant difference between two independent groups, and analysis of variance (ANOVA) was used for more than two groups. The categorical data such as sex, age groups, and social class were described using frequency and proportions while the Chi-square test was used to determine the level of the statistical differences. A p-value of $<0.05$ was considered statistically significant.

\section{Results}

A total of 99 children with SCA in steady state were recruited for the study. The mean age of the males and females was $8.02 \pm 5.11$ and $10.35 \pm 5.31$ years respectively, and children aged five to nine years constituted the majority $(28 ; 28.3 \%)$. There were $53(53.5 \%)$ males and $46(46.5 \%)$ females with a male-to-female ratio of 1.2:1. A higher proportion of the subjects $(75 ; 75.8 \%)$ were from low socioeconomic classes. Table 1 shows the sociodemographic characteristics of the study subjects. 


\section{Cureus}

\begin{tabular}{|c|c|c|}
\hline Characteristic & Frequency & Percentage \\
\hline \multicolumn{3}{|l|}{ Age (years) } \\
\hline $1-4$ & 27 & 27.3 \\
\hline 5-9 & 28 & 28.3 \\
\hline 10-14 & 23 & 23.2 \\
\hline$\geq 15$ & 21 & 21.1 \\
\hline \multicolumn{3}{|l|}{ Gender } \\
\hline Male & 53 & 53.5 \\
\hline Female & 46 & 46.5 \\
\hline \multicolumn{3}{|l|}{ SES } \\
\hline Low & 75 & 75.8 \\
\hline Middle & 18 & 18.2 \\
\hline High & 6 & 6.1 \\
\hline
\end{tabular}

TABLE 1: Sociodemographic characteristics of children with sickle cell anaemia

SES: socioeconomic status

The mean TLC was higher in children under five years and male subjects, while their mean Hb and platelet were lower compared to other age groups and female subjects. All subjects (99; 100.0\%) had anaemia. A total of 80 (80.8\%) subjects had leucocytosis while none had leucopoenia. Thrombocytosis and thrombocytopenia were seen in 30 (30.3\%) and seven (7.1\%) subjects respectively (Table 2).

\begin{tabular}{|c|c|c|c|c|c|c|}
\hline \multirow[t]{2}{*}{ Hb (n=99), n (\%) } & \multicolumn{3}{|c|}{ Total leucocyte count ( $n=99), n(\%)$} & \multicolumn{3}{|c|}{ Platelet (n=99), n (\%) } \\
\hline & High & Normal & Low & High & Normal & Low \\
\hline 99 (100.0) & $80(80.8)$ & $19(19.2)$ & $0(0.0)$ & $30(30.3)$ & $62(62.6)$ & $7(7.1)$ \\
\hline
\end{tabular}

TABLE 2: Hb, TLC and platelet categorization in children with sickle cell anaemia* *[6]

$\mathrm{Hb}$ : haemoglobin; TLC: total leucocyte count

High TLC (leucocytosis) was more common $(25 ; 25.3 \%)$ in subjects aged one to four years (under-five); the overall mean TLC was $14.3 \pm 4.5 \times 10^{3} / \mathrm{mm}^{3}$. The mean TLC was significantly higher in males $(15.42 \pm 5.11 \mathrm{x}$ $\left.10^{3} / \mathrm{mm}^{3}\right)$ when compared to female subjects $\left(12.98 \pm 3.18 \times 10^{3} / \mathrm{mm}^{3}\right)(\mathrm{p}=0.006)$. The mean TLC was higher in children under five years $\left(17.03 \pm 5.25 \times 10^{3} / \mathrm{mm}^{3}\right)$ compared to other age groups $(\mathrm{p}=0.002)$. The mean $\mathrm{Hb}$ was lower in males $(7.63 \pm 0.90 \mathrm{~g} / \mathrm{dL})$ compared to female subjects $(\mathrm{p}=0.038)$, and in subjects under five years $(7.76 \pm 1.17 \mathrm{~g} / \mathrm{dL}$ ) compared to other age groups $(\mathrm{p}=0.094)$. The mean corpuscular volume $(\mathrm{MCV})$ was $81.26 \pm$ $7.14 \mathrm{fl}$ but was statistically significantly lower in under-five subjects $(78.54 \pm 5.92 \mathrm{fl})(\mathrm{p}=0.047)$ compared to other age groups, and in male subjects $(79.86 \pm 6.98 \mathrm{fl})$ compared with females $(82.88 \pm 7.05 \mathrm{fl})(\mathrm{p}=0.036)$. The mean corpuscular haemoglobin $(\mathrm{MCH})$ was $28.63 \pm 2.90 \mathrm{pg}$. The under-five subjects had a statistically significant lower value $(26.79 \pm 2.53 \mathrm{pg}$ ) compared to other age groups $(\mathrm{p}=<0.001)$. The male participants had significantly lower MCH $(27.96 \pm 3.09 \mathrm{pg})$ compared with the females $(\mathrm{p}=0.012)$. The mean corpuscular haemoglobin concentration (MCHC) was $35.18 \pm 1.68 \mathrm{~g} / \mathrm{dL}$ and was significantly lower in under-five children $(34.04 \pm 1.59 \mathrm{~g} / \mathrm{dL})$ compared with other age groups $(\mathrm{p}<0.001)$. The mean MCHC was lower in male subjects $(34.91 \pm 1.81 \mathrm{~g} / \mathrm{dL})$, but the difference was not significant $(\mathrm{p}=0.088)($ Tables 3,4$)$. 


\section{Cureus}

mean platelet count was $391.5 \pm 182.6 \times 10^{3} / \mathrm{mm}^{3}$. The mean platelet count was lowest in under-five children, who had a mean value of $350.48 \pm 134.73 \times 10^{3} / \mathrm{mm}^{3}$, when compared with other age groups $(\mathrm{p}=0.060)$. The platelet was higher in male subjects, who had a mean platelet of $400.67 \pm 200.23 \times 10^{3} / \mathrm{mm}^{3}$ (Tables 3, 4).

\begin{tabular}{|c|c|c|c|c|c|c|}
\hline Variables & $1-4$ years & $5-9$ years & $10-14$ years & $15-18$ years & P-value & Overall \\
\hline $\mathrm{Hb}(\mathrm{g} / \mathrm{dl})$ & $7.66 \pm 1.08$ & $7.76 \pm 1.19$ & $7.72 \pm 1.11$ & $8.50 \pm 1.64$ & 0.094 & $7.89 \pm 1.27$ \\
\hline HCT (\%) & $21.56 \pm 2.99$ & $22.89 \pm 3.28$ & $21.80 \pm 2.90$ & $23.52 \pm 4.75$ & 0.189 & $22.41 \pm 3.52$ \\
\hline MCV (fl) & $78.57 \pm 5.92$ & $80.92 \pm 8.22$ & $82.17 \pm 6.90$ & $84.20 \pm 6.37$ & 0.047 & $81.26 \pm 7.14$ \\
\hline $\mathrm{MCH}(\mathrm{pg})$ & $26.80 \pm 2.53$ & $28.44 \pm 2.82$ & $29.38 \pm 2.26$ & $30.44 \pm 2.81$ & 0.001 & $28.63 \pm 2.90$ \\
\hline $\mathrm{MCHC}(\mathrm{g} / \mathrm{dl})$ & $34.04 \pm 1.59$ & $35.18 \pm 1.87$ & $35.79 \pm 1.24$ & $35.98 \pm 1.10$ & 0.001 & $35.18 \pm 1.68$ \\
\hline $\operatorname{TLC}\left(10^{3} / \mathrm{mm}^{3}\right)$ & $17.03 \pm 5.26$ & $13.77 \pm 4.26$ & $12.74 \pm 3.55$ & $13.16 \pm 3.04$ & 0.002 & $14.29 \pm 4.47$ \\
\hline Platelet $\left(10^{3} / \mathrm{mm}^{3}\right)$ & $350.5 \pm 134.7$ & $457.3 \pm 240.3$ & $371.6 \pm 156.8$ & $378.1 \pm 160.8$ & 0.060 & $391.5 \pm 182.6$ \\
\hline
\end{tabular}

TABLE 3: Haematological profile of children with sickle cell anaemia based on age group

$\mathrm{Hb}$ : haemoglobin; MCV: mean corpuscular volume; $\mathrm{MCH}$ : mean corpuscular haemoglobin; MCHC: mean corpuscular haemoglobin concentration; TLC: total leucocyte count

\begin{tabular}{|c|c|c|c|}
\hline Investigation & Males & Females & P-value \\
\hline $\mathrm{Hb}(\mathrm{g} / \mathrm{dl})$ & $7.63 \pm 0.90$ & $8.16 \pm 1.56$ & 0.027 \\
\hline НCT (\%) & $21.86 \pm 2.53$ & $23.03 \pm 4.32$ & 0.100 \\
\hline MCV (fl) & $79.86 \pm 6.98$ & $82.88 \pm 7.05$ & 0.036 \\
\hline $\mathrm{MCH}(\mathrm{pg})$ & $27.96 \pm 3.09$ & $29.42 \pm 2.48$ & 0.012 \\
\hline $\mathrm{MCHC}(\mathrm{g} / \mathrm{dl})$ & $34.91 \pm 1.81$ & $35.49 \pm 1.47$ & 0.088 \\
\hline $\operatorname{TLC}\left(10^{3} / \mathrm{mm}^{3}\right)$ & $15.43 \pm 5.11$ & $12.98 \pm 3.18$ & 0.006 \\
\hline Platelet $\left(10^{3} / \mathrm{mm}^{3}\right)$ & $400.67 \pm 200.23$ & $380.848 \pm 150.99$ & 0.593 \\
\hline
\end{tabular}

\section{TABLE 4: Haematological profile of children with sickle cell anaemia based on gender}

$\mathrm{Hb}$ : haemoglobin; MCV: mean corpuscular volume; $\mathrm{MCH}$ : mean corpuscular haemoglobin; $\mathrm{MCHC}$ : mean corpuscular haemoglobin concentration; TLC: total leucocyte count

\section{Discussion}

In this study, leucocytosis (elevated TLC) was a characteristic finding in children with SCA; it was seen in more than two-thirds of the subjects. This finding is similar to the reports of other studies $[7,8]$. The leucocytosis in SCA at steady state has been hypothesised to be a reflection of the constant inapparent inflammation with consequent cytokine release ultimately leading to increased leucocyte production in the bone marrow [9]. In this study, the mean leucocytosis was significantly higher in subjects who were less than five years of age compared to older children. Similar findings have been documented by West et al. [10]. The higher mean leucocytosis in under-five children with SCA may be due to an increased incidence of covert and overt infections that occur in younger children [11]. This may also explain the increased mortality in young children with SCA as leucocytosis has been shown to be a significant risk factor for early death in SCA [12].

In this study, the mean leucocytosis was significantly higher in male subjects compared to females. This is similar to findings by Abubakar et al. and Iheanacho et al. who have also reported higher TLC values in male subjects with SCA $[7,8]$. Elevated platelet count (thrombocytosis) was seen in one-third of the children with SCA. This is consistent with findings relating to thrombocytosis that have been reported by other similar 
studies $[7,8,13]$. Thrombocytosis in SCA has been variably attributed to anaemia-induced increased erythropoietin secretion that has similar homology to thrombopoietin with consequent thrombopoiesis and decreased pooling of platelets in splenic circulation due to functional and/or structural asplenia characteristic of SCA $[14,15]$. The mean platelet was lowest in under-five subjects in the current study. This might be due to relatively intact splenic function and structure in the younger age group, causing platelets to be largely pooled in the spleen, unlike older children whose spleen have undergone recurrent infarction that characterises SCA. However, this finding contrasts with Iheanacho's report, who adduced the observed decreased platelet with age to reduced thrombopoietin in adults [8]. However, this may not be the case as platelet count in SCA is dependent on more than one factor $[14,15]$. This will probably explain the significantly higher platelet count in male subjects in the current study. The males were albeit younger and thus lower platelet count was expected; their higher degree of anaemia might have caused the elevated platelet [15]. Thus, in children with SCA, the lower platelet count is dependent on younger age, a higher degree of anaemia, among other factors.

All subjects (100\%) had low $\mathrm{Hb}$ in this study. Other studies have shown that low $\mathrm{Hb}$ in children with SCA is caused by reduced RBC life span (one-seventh of normal), low erythropoietin response and nutritional deficiency $[10,16,17]$. These would explain the low $\mathrm{Hb}$ in all the subjects as more than two-thirds were from low socioeconomic class. This finding is similar to other reports $[7,8]$. The mean $\mathrm{Hb}$ was lowest in under-five subjects and younger male subjects in this study. The low $\mathrm{Hb}$ in younger subjects is similar to the reports by Iheanacho et al. [8], while the low $\mathrm{Hb}$ in males is similar to the report by Abubakar et al. [7]. Iheanacho et al. [8] and Rao et al. [18] have reported higher $\mathrm{Hb}$ in males, although they were not statistically significant. The younger age of male subjects and the predominantly low socioeconomic status of under-five subjects in the current study might explain the observed low mean $\mathrm{Hb}[17,19]$. The mean $\mathrm{MCV}, \mathrm{MCH}$ and $\mathrm{MCHC}$, which are the markers of iron status, were all within normal ranges [20]. This finding is similar to other reports $[7,21,22]$. The normal iron markers in children with SCA may be attributed to increased red cell turnover and repeated blood transfusion. The values in under-five and male subjects were lowest in this study, probably due to age variability factor and low socioeconomic status $[17,19]$.

\section{Conclusions}

Leucocytosis, thrombocytosis, low $\mathrm{Hb}$ and normal iron markers (MCV, MCH, MCHC) are the characteristic features in children with SCA, and these features are predominantly found among children under five years of age compared to other age groups. Close monitoring of under-five children with SCA is thus highly recommended.

\section{Additional Information \\ Disclosures}

Human subjects: Consent was obtained by all participants in this study. Federal Teaching Hospital Gombe Research and Ethics committee issued approval NHR/25/10/2013. This study was approved by the Research and Ethics committee of the Federal Teaching Hospital, Gombe. Animal subjects: All authors have confirmed that this study did not involve animal subjects or tissue. Conflicts of interest: In compliance with the ICMJE uniform disclosure form, all authors declare the following: Payment/services info: All authors have declared that no financial support was received from any organization for the submitted work. Financial relationships: All authors have declared that they have no financial relationships at present or within the previous three years with any organizations that might have an interest in the submitted work. Other relationships: All authors have declared that there are no other relationships or activities that could appear to have influenced the submitted work.

\section{References}

1. World Health Organization - sickle-cell anaemia: report by the Secretariat . (2006). Accessed: September 24, 2020: https://apps.who.int/iris/handle/10665/20890.

2. Omotade OO, Kayode CM, Falade SL, Ikpeme S, Adeyemo AA, Akinkugbe FM: Routine screening for sickle cell haemoglobinopathy by electrophoresis in an infant welfare clinic. West Afr J Med. 1998, 17:91-4.

3. Powars DR: Sickle cell anemia and major organ failure. Hemoglobin. 1990, 14:573-98. 10.3109/03630269009046967

4. Akar NA, Adekile A: Ten-year review of hospital admissions among children with sickle cell disease in Kuwait. Med Princ Pract. 2008, 17:404-8. 10.1159/000141506

5. Kaul DK, Fabry ME, Nagel RL: The pathophysiology of vascular obstruction in the sickle syndromes . Blood Rev. 1996, 10:29-44. 10.1016/s0268-960x(96)90018-1

6. Wammanda RD, Ogala WN: Haemopoiesis. Paediatrics and Child Health in a Tropical Region. Azubuike JC, Nkanginieme KE (ed): African Educational Services, Owerri, Nigeria; 2016. 3:1037-41.

7. Abubakar Y, Ahmad HR, Faruk JA: Hematological parameters of children with sickle cell anemia in steady and crisis states in Zaria, Nigeria. Ann Trop Pathol. 2019, 10:122-5. 10.4103/atp.atp_22_19

8. Iheanacho OE: Haematological parameters of adult and paediatric subjects with sickle cell disease in steady state, in Benin City, Nigeria. Int Blood Res Rev. 2015, 3:171-7. 10.9734/IBRR/2015/18339

9. Akinola NO, Stevens SM, Franklin IM, Nash GB, Stuart J: Subclinical ischaemic episodes during the steady state of sickle cell anaemia. J Clin Pathol. 1992, 45:902-6. 10.1136/jcp.45.10.902

10. West MS, Wethers D, Smith J, Steinberg M: Laboratory profile of sickle cell disease: a cross-sectional 
analysis. The Cooperative Study of Sickle Cell Disease. J Clin Epidemiol. 1992, 45:893-909. 10.1016/08954356(92)90073-v

11. Leikin SL, Gallagher D, Kinney TR, Sloane D, Klug P, Rida W: Mortality in children and adolescents with sickle cell disease. Cooperative Study of Sickle Cell Disease. Pediatrics. 1989, 84:500-8.

12. Maitra P, Caughey M, Robinson L, et al.: Risk factors for mortality in adult patients with sickle cell disease: a meta-analysis of studies in North America and Europe. Haematologica. 2017, 102:626-36. 10.3324/haematol.2016.153791

13. Akinbami A, Dosunmu A, Adediran A, Oshinaike O, Adebola P, Arogundade O: Haematological values in homozygous sickle cell disease in steady state and haemoglobin phenotypes AA controls in Lagos, Nigeria. BMC Res Notes. 2012, 5:396. 10.1186/1756-0500-5-396

14. Ataga KI, Orringer EP: Hypercoagulability in sickle cell disease: a curious paradox . Am J Med. 2003, 115:7218. 10.1016/j.amjmed.2003.07.011

15. Ahmed SG, Onwukeme KE: Platelet count and its relationship to haematocrit in sickle cell anaemia in steady state. Niger Postgraduate Med J. 1997, 4:4-6.

16. Sherwood JB, Goldwasser E, Chilcote R, Carmichael LD, Nagel RL: Sickle cell anemia patients have low erythropoietin levels for their degree of anemia. Blood. 1986, 67:46-9.

17. Animasahun BA, Temiye EO, Ogunkunle OO, Izuora AN, Njokanma OF: The influence of socioeconomic status on the hemoglobin level and anthropometry of sickle cell anemia patients in steady state at the Lagos University Teaching Hospital. Niger J Clin Pract. 2011, 14:422-7. 10.4103/1119-3077.91748

18. Rao SS, Goyal JP, Raghunath SV, Shah VB: Hematological profile of sickle cell disease from South Gujarat, India. Hematol Rep. 2012, 4:e8. 10.4081/hr.2012.e8

19. Pluncevic Gligoroska J, Gontarev S, Dejanova B, Todorovska L, Shukova Stojmanova D, Manchevska S: Red blood cell variables in children and adolescents regarding the age and sex. Iran J Public Health. 2019, 48:704-12.

20. World Health Organization: haemoglobin concentrations for the diagnosis of anaemia and assessment of severity. (2011). Accessed: October 17, 2020: https:/www.who.int/vmnis/indicators/haemoglobin/en/.

21. Sani MA, Adewuyi JO, Babatunde AS, Olawumi HO, Shittu RO: The iron status of sickle cell anaemia patients in Ilorin, North Central Nigeria. Adv Hematol. 2015, 2015:386451. 10.1155/2015/386451

22. Odunlade O, Adeodu O, Owa J, Obuotor E: Iron deficiency, still a rarity in children with sickle cell anemia in Ile-Ife, Nigeria. Hematol Transfus Cell Ther. 2019, 41:216-21. 10.1016/j.htct.2018.11.006 